\section{THE INFLUENCE OF THE EMOTIONAL SPHERE ON THE SELF-ESTEEM OF THE INDIVIDUAL}

УдК 159.922

DOI https://doi.org/10.32843/26635208.2020.18.2.7

\section{Головська І.Г.}

к.психол.н., доцент,

доцент кафедри теорії та методики практичної психології

Південноукраїнський національний педагогічний університет

імені К.Д. Ушинського

Почепцова Д.О.

студентка

Південноукраїнський національний педагогічний університет

імені К.Д. Ушинського

\begin{abstract}
у статті розглядається вплив емоційної сфери на самооцінку особистості. Основна увага приділяється поглибленню знань та уявлень про фрундамент емоційної сфрери, а також розкриттю сутності самооцінки в юнацькому віці. Метою роботи було дослідити вплив емоційної ссеери на самооцінку особистості. Предметом дослідження стали особливості впливу емоційної сфрери насамооцінкуособистості. Основні завдання дослідження - провести аналіз поняття «емоція» та фракторів, які впливають на емоційні реакції, розглянути поняття самооцінки й фрактори ії формування, провести експериментальне дослідження впливу емоцій на прояв самооцінки. Методами дослідження обрано аналіз і синтез; порівняння, класифрікацію, конкретизацію, узагальнення, у статті використано такі методики: тест-опитувальник «Визначення рівня самооцінки» С.В. Ковальова; методику самооцінки та рівня домагань Дембо-Рубінштейна; самооціночний тест «Характеристики емоційності» (Е.П. Ільїна), математико-статистична обробка даних проведена за допомогою програми Microsoft Excel. Для емпіричного дослідження запрошено юнаків віком від 17 до 21 року. Такий віковий діапазон респондентів вибрано через те, що саме в період юнацтва триває розвиток від зовнішнього управління до самоврядування. У цьому віці самооцінка може стати важливим регулятором поведінки індивіда. Змінюється значення різних рис особистості. Тож дослідження показало, що емоції впливають як на низьку, так і на високу самооцінку, але респонденти, які мають низьку самооцінку й піддаються емоціям, мають більш негативний вплив, тому що такий прояв впливає на їхню діяльність і вміння взаємодіяти з людьми. На підставі трьох методик нами виявлено, що загалом самооцінка в групі знаходиться на середньому (60\%) та вище середнього (24\%) рівнях, а емоційність, у свою чергу, - на середньому (72\%) рівні. Гіпотезою дослідження є те, що емоції являють собою фрактор, який впливає на прояв самооцінки, що негативно впливає на ефрективність діяльності та спілкування. Ключові слова: самооцінка, емоційна ссрера самоствердження, класифрікація емоцій, фунндаментальні емоції, юнацький вік.
\end{abstract}

The article considers the influence of the emotional sphere on the self-esteem of the individual. The main attention is paid to the deepening of knowledge and ideas about the foundation of the emotional sphere, as well as the disclosure of the essence of self-esteem in adolescence. The aim of the work was to investigate the influence of the emotional sphere on the self-esteem of the individual. The subject of the study were the features of the influence of the emotional sphere on the self-esteem of the individual. The main objectives of the study were to analyze the concept of "emotion" and the factors that affect emotional reactions, to consider the concept of self-esteem and factors of its formation, to conduct an experimental study of the influence of emotions on self-esteem. Analysis and synthesis are chosen by research methods; comparison, classification, specification, generalization, the following methods are used in the article: Testquestionnaire "Determination of self-esteem" S.V. Kovalev; Methods of self-assessment and the level of claims Dembo-Rubinstein; Selfassessment test "Characteristics of emotionality" (E.P. Ilyin), mathematical and statistical data processing was carried out by using Microsoft Excel. Young people aged 17 to 21 were invited for the empirical study. This age range of respondents was chosen because it is during adolescence that development from external governance to self-government continues. At this age, self-esteem can become an important regulator of individual behavior. The value of different personality traits changes. Therefore, research has shown that emotions affect both low and high self-esteem, but respondents who have low self-esteem and are exposed to emotions have a more negative impact because such manifestations affect their performance and ability to interact with people. Based on three methods, we found that in general, selfesteem in the group is on average (60\%) and above average (24\%), and emotionality in turn is on average (72\%). The hypothesis of the study is that emotions are a factor that affects the manifestation of self-esteem, which entails a negative impact on the effectiveness of activities and communication

Key words: self-esteem, emotional sphere, self-affirmation, classification of emotions, fundamental emotions, adolescence.
Постановка проблеми. Тема дослідження пов'язана з тим, що на тлі великої кількості досліджень самооцінки питання про впив емоційної сфери на самооцінку особистості мало привертало увагу дослідників. Хоча самооцінка визначає життєві позиції людини, впливає на формування поведінки, її сферу інтересів і майбутні перспективи. В умовах сучасного стану суспільства зміна політичних, соціально-економічних відносин, ускладнення вироб- ничої діяльності, зміна характеру праці і способу життя великих мас населення, а також виникнення постійних стресових ситуацій не лише ставлять високі вимоги до інтелектуального й емоційно-вольового потенціалу особистості, а й позначають настанови розвитку самооцінки особистості.

Аналіз основних досліджень і публікацій. Самооцінка є надзвичайно важливою для повноцінного функціонування особистості 
в соціальному середовищі та досягнення різних життєвих цілей - успіху, самореалізації, сімейного щастя, духовного й матеріального благополуччя. Вона тісно пов'язана з деякими найважливішими емоціями, тобто з тривожністю, відчуттям щастя, печалі тощо. На думку К. Хорні, самооцінка - це складна особистісна формація, що стосується базових властивостей особистості. Вона відображає те, що людина з'ясує про себе від інших, і власну діяльність, спрямовану на розуміння своїх дій та особистих якостей. Ставлення людини до себе - це останній розвиток у системі її світогляду. Однак самооцінка відіграє особливо головну роль у структурі особистості [10].

Самооцінка пов'язана з однією з основних потреб особистості - необхідністю в самоствердженні, що визначається співвідношенням її фактичних досягнень до рівня прохання. На практиці людина зазвичай прагне досягти таких результатів, які відповідають її самооцінці, сприяють її покращенню, стандартизації. Отже, функції самооцінки особистості полягають у тому, що вони виступають як внутрішні умови регуляції людської поведінки та діяльності. За словами Л.Д. Столяренко, людина, включаючи самооцінку в структуру мотивації діяльності, постійно співвідносить свої здібності, розумові ресурси із цілями та засобами діяльності [9].

Постановка завдання. Мета статті - дослідити вплив емоційної сфери на самооцінку особистості.

Виклад основного матеріалу дослідження. Під впливом оцінки інших індивід поступово розвиває власне ставлення до себе та самооцінку своєї особистості, а також певні форми їх діяльності: спілкування, поведінку, активність, досвід. Маючи оптимальну, адекватну самооцінку, суб'єкт правильно співвідносить свої можливості та здібності, критично ставиться до себе, хоче реально подивитися на свої невдачі й успіхи, намагається ставити цілі, яких можна досягти на практиці. Він не тільки оцінює те, чого досяг за власними мірками, а й намагається передбачити, як реагуватимуть на це інші люди: однокласники та родичі.

До оптимальних зараховують самооцінку «високого рівня» та «вище середнього» (людина заслуговує на оцінку, поважає себе, задоволена собою), а також «середній рівень» (людина поважає себе, але знає свої слабкі сторони й прагне до вдосконалення, саморозвитку). Але самооцінка може бути неоптимальною - занадто високою або занадто низькою. Якщо людина недооцінює себе порівняно з тим, якою вона $€$ насправді, то ії самооцінка знижується. Коли вона завищує свої здібності, результати діяльності, особисті якості, зовнішність, то характеризується високою самооцінкою. Неадекватна самооцінка ускладнює життя не тільки тих, хто її має, а й оточуючих, тих людей, які взаємодіють із ними в різних ситуаціях. Конфліктні ситуації, у яких людина опиняється, часто є наслідком неправильної самооцінки.

У практичній психології існує два різновиди низької самооцінки: низька самооцінка в поєднанні з низьким рівнем домагань і поєднання низької самооцінки з високим рівнем домагань. У першому випадку люди схильні перебільшувати свої недоліки, відповідно, розглядають свої досягнення як нагороду інших людей або приписують унаслідок простої удачі. Іншому випадок, який має назву «афект неадекватності», може свідчити про процес розвитку комплексу неповноцінності, внутрішньої тривожності особистості. Подібні люди хочуть бути першими в усьому, тому будь-яка ситуація дослідження їхньої компетентності вважається емоційно дуже складною та може передбачати загрозу. Т.І. Гусєва вважає: «Надвисока самооцінка призводить до того, що людина завищує себе та свої можливості. Як результат, у неї є необґрунтовані претензії, часто не підтримувані іншими» [2]. Психологічні дослідження, описані В. Квіном у праці «Прикладна психологія», переконливо доводять, що характеристики самооцінки впливають і на емоційні взаємини, і на ступінь задоволеності своєю роботою, навчанням, життям і стосунками з іншими. Однак самооцінка також залежить від описаних вище факторів [6].

«Емоція - це поширена активна форма переживання організмом своєї життєвої діяльності», - пише Г.С. Костюк [7]. Емоції бувають як простими, так і складними. Маленькі дрібниці, що викликають у нас задоволення, утома, енергія, сум, біль - це прості емоції. Такі емоції характерні як людям, так і тваринам. У результатіжиттєдіяльностіпрості емоції людинистали складними емоціями та почуттями. Характерним для складних емоцій є те, що вони виникають у результаті усвідомлення предмета, який їх пробудив, розуміння їх життєвого значення. Прикладом таких емоцій $є$ відчуття задоволення від сприйняття музики, картин і пейзажу. Емоції характеризуються полярністю. Вони проявляються в тому, що кожна емоція, кожне почуття за різних причин можуть проявлятися протилежним чином: «радість - горе», «любов - ненависть», «співчуття - антипатія», «задоволення - незадоволення». Такі переживання мають яскраво виражений позитивний чи негативний відтінок.

Існує багато класифікацій емоцій. Найчастіше емоції поділяються на такі критерії групи:

1. Нижчі та вищі емоції;

2. Позитивні та негативні;

3. Стенічні та астенічні;

4. Емоційні реакції та умови. 
Нижчі та вищі емоції. В. Джеймс уважає, що задоволення функціональних потреб належить нижчим органам почуттів [11]. Вищі почуття зазвичай виникають при задоволенні духовних потреб. Ці емоції мають яскраво виражений соціальний характер і свідчать про ставлення людини до різних сторін і явищ суспільного життя-моральних, інтелектуальних, естетичних.

Позитивні та негативні емоції. Уважається, що позитивні емоції - це корисні емоції для людини, а негативні - для неї шкідливі. На думку К. Ізарда, позитивні емоції полегшують взаємодію людей, їх розуміння ситуацій і взаємовідносин між предметами, а негативні $є$ шкідливими та не сприяють взаємодії [4]. Деякі психологи вважають це міркування неправильним. Набагато ближче до істини твердження, що позитивні емоції просто асоціюються із задоволенням, а негативні емоції пов'язані з неприємністю їх безпосереднього переживання.

Стенічними (від грецького «stenos» - сила) називають емоції, що підвищують життєву активність організму, астенічними - емоції, які викликають відчуття пригнічення, знижують енергію життєдіяльності суб'єкта. Попри те що астенічні емоції користуються поганою репутацією, неправильно було б сказати, що астенічні емоції $\epsilon$ абсолютно шкідливими. Біологічно вони необхідні, принаймні для того щоб надавати спокій перевантаженому організму, щоб захистити його від перенапруження. За силою і тривалістю проявів розрізняють кілька видів емоцій: афект, пристрасть, емоції, настрої, почуття і стрес.

Афект - це найпотужніша емоційна реакція, що повністю захоплює психіку людини. Зазвичай це відбувається в умовах, коли людина не може впоратися з ситуацією. Відмінними рисами афекту є ситуативність, узагальнення, коротка тривалість і висока інтенсивність. Відбувається мобілізація всього організму, рухи імпульсивні. Афект майже неконтрольований і не підкоряється контролю волі.

Пристрасть - це сильне, наполегливе, довготривале почуття, яке захоплює й володіє людиною. По силі вона наближається до грації, а по тривалості - до почуттів. Емоції у вузькому розумінні мають ситуативний характер, виражають оцінку утворюваних чи можливих ситуацій. Насправді емоції можуть погано проявлятися в зовнішній поведінці, якщо людина здатна вміло приховувати власні емоції, то зазвичай важко здогадатися, що вона переживає.

Почуття - це найсильніші емоційні стани. Вони мають предметний характер. Це завжди почуття до чогось, до когось. Їх іноді називають «вищими» емоціями, оскільки вони виникають, коли задовольняються потреби найвищого порядку.
Настрій - це стан, який малює наші емоції, загальний емоційний стан протягом певного часу. На відміну від емоцій і почуттів, настрій не об'єктивний, а особистий; це не ситуативно, але розтягується в часі. С.Д. Максименко вважає, що настрій - це загальний емоційний стан, який своєрідно забарвлює діяльність людини протягом певного часу, характеризує її життєву силу [8]. Виділяють позитивні настрої, що проявляються в бадьорості, і негативні, які пригнічують, демобілізують, викликають пасивність. Ступінь відповідності індивідуальна. Особи, які характеризуються самоконтролем, не піддаються настрою, не втрачають серця навіть у тих випадках, коли для цього є якісь причини, а, навпаки, борються з труднощами. Малодушні швидко піддаються настроям. Ïм потрібна підтримка команди.

Емоції відіграють дуже вагому роль у житті людей. Емоційна сфера людини - це широке коло ії переживань і почуттів. Вона виконує низку функцій, таких як стимулювання, регулювання, усунення дефіциту інформації, головною з яких $є$ оцінка. Виникнення та прояв емоцій пов'язані зі складною роботою кори головного мозку та підкіркової тканини, а також вегетативної нервової системи. Провідна роль належить корі, але важлива також підкірка, оскільки вона містить центри, що контролюють вегетативну нервову систему й регулюють функцію внутрішніх органів. Це визначає тісний взаємозв'язок емоцій і почуттів з різними змінами функцій організму: з діяльністю серця, судин, органів дихання, зі змінами в діяльності скелетних м'язів, зокрема у вигляді виразних рухів цілого тіла (пантоміма) та міміки обличчя (вираз обличчя). Людина, що відчуває певний емоційний стан - радість, смуток, гнів, зазнає певних змін не тільки у внутрішніх органах, а й у зовнішньому вигляді. Змінюється вираз на обличчі та очах, з'являються жести певного характеру, виникають конкретні відтінки інтонації. Із цих змін можна судити, яку емоцію переживає людина в цей момент.

Завдяки емоціям люди усвідомлюють свої потреби та предмети, на які вони спрямовані. Ще одна спільна особливість емоцій, на які потрібно звернути увагу, - це їх допомога в задоволенні потреб і досягненні певних цілей. Оскільки будь-яка емоція є позитивною чи негативною, людина може судити про досягнення мети. Так, позитивні емоції завжди пов'язані з отриманням бажаного результату, а негативні, навпаки, - 3 невдачею поставленої мети. Отже, можна зробити висновок, що емоції найбільш безпосередньо пов'язані з регуляцією діяльності людини.

Емоція - це те, що переживається як почуття, яке мотивує, організовує та спрямовує сприйняття, мислення й дії. У роботах Дарвіна, сучасних учених емоції класифіку- 
ються як основні, зазначається, що вони однаково проявляються в представників різних культур. Фундаментальні емоції забезпечуються вродженими нейронними програмами. (Вроджений механізм прояву гніву передбачає усмішку як демонстрацію готовності кинутися на ворога й кусати його; багато людей у гніві, навпаки, стискають зуби та губи, ніби намагаючись пом'якшити або замаскувати маску прояви гніву.)

К. Ізард виділив такі основні, «фундаментальні емоції»:

1. Інтерес (як емоція) - це позитивний емоційний стан, який сприяє розвитку навичок і знань, спонукає до навчання.

2. Радість - це позитивний емоційний стан, пов'язаний зі здатністю повністю задовольнити фактичну потребу, імовірність якої до цього моменту була невеликою або в будьякому випадку невизначеною.

3. Сюрприз - емоційна реакція на раптові обставини, яка не має чітко визначеного позитивного чи негативного ознаки. Сюрприз гальмує всі попередні емоції, спрямовуючи увагу на об'єкт, який його викликав, і може обернутися інтересом.

4. Страждання - це негативний емоційний стан, пов'язаний із достовірною або, здавалося б, отриманою інформацією про неможливість задоволення найважливіших життєвих потреб, який до цього моменту здавався більш-менш вірогідним, найчастіше виникає у вигляді емоційного стресу.

5. Гнів - це емоційний стан, який має негативний характер, зазвичай протікає у формі афекту й викликаний раптовим виникненням серйозної перешкоди для задоволення надзвичайно важливої потреби суб'єкта.

6. Відраза - це негативний емоційний стан, спричинений предметами (предметами, людьми, обставинами тощо), контакт із якими (фізіологічна взаємодія, спілкування в спілкуванні тощо) вступає в різкий конфлікт з ідеологічними, моральними чи естетичними принципами й установками предмет. Огида, якщо поєднується з гнівом, може мотивувати агресивну поведінку в міжособистісних стосунках, де напад мотивується гнівом, а огида мотивована бажанням позбутися когось або чогось.

7. Презирство - це негативний емоційний стан, який виникає в міжособистісних стосунках і породжується невідповідністю життєвих позицій, поглядів і поведінки суб'єкта життєвим позиціям, поглядам і поведінці об'єкта почуття. Останні представлені предмету як база, що не відповідає прийнятим моральним нормам та естетичним критеріям.

8. Страх - це негативний емоційний стан, який проявляється, коли суб'єкт отримує інформацію про можливу загрозу для свого життя, про реальну чи уявну небезпеку. На відміну від емоцій страждання, викликаних безпосереднім блокуванням найважливіших потреб, людина, яка переживає емоцію страху, має лише ймовірний прогноз можливої хвороби й діє на основі цього (часто недостатньо надійного або перебільшеного прогнозу).

9. Сором - це негативний стан, що виражається в усвідомленні невідповідності власних думок, дій і зовнішнього вигляду не лише очікуванням інших, а й власним уявленням про відповідну поведінку та зовнішній вигляд.

10. Збентеження [4].

З поєднання фундаментальнихемоцій виникають складні емоційні стани, такі як, наприклад, тривога, яка може поєднувати страх, гнів, провину та інтерес, що, у свою чергу, формують низьку самооцінку. Тривога - це не окреме явище, а свого роду складне емоційне переживання, де страх є найбільш значущим елементом. Страх виступає як основа низької самооцінки. Він суттєво обмежує сприйняття, мислення та свободу вибору. Крім того, страх обмежує свободу поведінки людини. У страху, людина перестає належати до себе, їі рухає одне єдине бажання - усунути загрозу, уникнути небезпеки. Страх іноді викликає сонливість, повну нездатність рухатися. Через страх, тривогу й сором'язливість виникає низька самооцінка, яка й заважає людині нормально існувати. Але водночас у людей із завищеною самооцінкою також переважає страх, але в іншій формі прояву. Такі люди, навпаки, бояться бути не помітними, невпевненими в собі, слабкими й безпорадними, унаслідок чого вони стають більш агресивними та часто вступають у конфлікти з людьми, чий рівень самооцінки нижчий.

Юнацький період - це період інтенсивного формування самооцінки, швидкого розвитку самосвідомості як здатності спрямовувати свідомість до власних психічних процесів, включаючи складний світ своїх переживань, і необхідності пізнавати себе як людину. у юнацькому віці самооцінка може стати важливим регулятором поведінки індивіда. Змінюється значення різних рис особистості. У юнаків головним критерієм оцінювання себе та іншого є морально-психологічні характеристики людини, що проявляються у взаєминах з іншими. У цей період триває розвиток від зовнішнього управління до самоврядування, яке починається в підлітковому віці. У юнацькому віці людина переглядає багато цінностей, зосереджуючись головним чином на референтній групі у своїх смаках і зразках. До юнацького віку людина має більш диференційовану оцінкувласної поведінки в різнихситуаціях, існує деталізована система самооцінки й в основному формується «самоімідж» - відносно стійка система самообразу. Уже сформована здатність молоді до узагальнення дає 
змогу робити узагальнення в досить складній галузі - діяльності з оволодіння нормами людських відносин [1]. Тому провідною діяльністю молоді є інтимно-особисте спілкування в різних сферах. Це дає їм можливість самовиражатися й самостверджуватися. Самооцінка свого місця в суспільстві відіграє якщо не вирішальну, то одну з головних ролей у формуванні особистості, багато в чому визначаючи соціальну адаптацію та дезадаптацію особистості як регулятора поведінки й діяльності.

Для дослідження впливу емоційної сфери на самооцінку особистості використано три методики, дві з яких спрямовані на визначення самооцінки, а одна - на дослідження емоційності індивіда: 1) тест-опитувальник «Визначення рівня самооцінки» С.В. Ковальова; 2) методику самооцінки та рівня домагань Дембо-Рубінштейна; 3) самооціночний тест «Характеристики емоційності» (Е.П. Ільїна). Завдяки методикам нами виявлено, що загалом самооцінка в групі знаходиться на середньому (60\%) та вище середнього (24\%) рівнях, а емоційність, у свою чергу, - на середньому (72\%) рівні. Дослідження показало, що емоції впливають як на низьку, так і на високу самооцінку, але респонденти, які мають низьку самооцінку й піддаються емоціям, мають більш негативний вплив, тому що такий прояв впливає на їхню діяльність і вміння взаємодіяти з людьми.

Висновки 3 проведеного дослідження. Отже, варто сказати, що люди з низькою самооцінкою менш емоційні, ніж люди із завищеною самооцінкою, тому що будь-який прояв емоції - це прояв себе, привертання уваги, на фоні чого й виникає емоція сорому. У людей із завищеною самооцінкою, навпаки, емоційність на високому рівні. Вони люблять привертати увагу та постійно хочуть бути в центрі неї, що і $€$ великим проявом емоцій. Установлено, що молоді люди, які негативно сприймаються однолітками, мають нижчу самооцінку, і навпаки. Отже, у підлітковому віці продовжує розвиватися справжня самооцінка - самооцінка людини переважаючої залежності від критеріїв внутрішнього світу, зумовлена власним «я». Це не означає, що оцінка інших людей зараз не суттєва: вона просто перестає відігравати домінуючу роль.

\section{ЛITЕРАТУРА:}

1. Бороздіна Л.В. Що таке самооцінка? Психол. журн. 1992. № 4. С. 99-100.

2. Гусева Т.И. Психология личности. Шпаргалки. Москва, 2008. 30 с.

3. Захарова О.В. Психологія фрормування самооцінки. Мінськ : Белінкоммаш, 1993. 99 с.

4. Изард К.Э. Психология эмоций. Санкт-Петербург, 2000. 27 с., 63 с.

5. Ильин Е.П. Эмоции и чувства. Санкт-Петербург : Питер, 2001. 553 с.

6. Квинн В. Прикладная психология. Санкт-Петербург, 2000. 560 с.

7. Костюк Г.С. Психологія. Київ, 1988. 25 с.

8. Максименко С.Д., Соловієнко В.О. Загальна психологія : навчальний посібник. Київ : МАУП, 2000. 256 c.

9. Столяренко Л.Д. Основы психологии : учебник. Москва : Проспект, 2016. 180 с.

10. Хорни К. Невротическая личность нашего времени. Самоанализ. Москва, 1993. 478 с.

11. James W. Principles of Psychology. New York : Holt, 1890. 712 p. 